\title{
Raw Material of Nicotine Isolated From Tobacco Leaves Cultivated in Indonesia
}

\author{
Arifayu Addiena Kurniatri ${ }^{1 *}$, Nanang Yunarto ${ }^{1}$, Intan Sari Oktoberia ${ }^{1}$, Winarsih ${ }^{1}$, \\ Herni Asih Setyorini ${ }^{1}$, Uud Nourma Reswandaru ${ }^{1}$
}

${ }^{1}$ Center for Biomedical Research and Development of Basic Health Technology, National Institute of Health Research and Development, Jakarta, Indonesia

*Corresponding author: arifayu_ak@litbang.kemkes.go.id

\begin{abstract}
Indonesian tobacco is largely used for cigarettes. The Indonesian cigarettes export market is currently affected because many countries have signed the Framework Convention on Tobacco Control (FCTC) which is under the auspices of the World Health Organization (WHO). Exploration of the potential of tobacco as a raw material of a hygienic product is an alternative solution for the sustainability of tobacco cultivation while increasing the empowerment of tobacco farmers. The high nicotine content of tobacco is needed to be used as raw material of a hygienic product. The purpose of this research is to isolate nicotine from tobacco leaves and find out the tobacco with the highest nicotine content. The design of this study is experimental laboratory. Tobacco leaf samples were taken from tobacco producing regions in Indonesia. Nicotine was isolated from tobacco leaves using ethanol 96\%. Quantitative analysis of nicotine compound was carried out using Gas Chromatography Mass Spectroscopy (GCMS). The result showed nicotine content in tobacco leaf samples ranged $0.08-2.53 \%$ and the highest nicotine content is in tobacco samples from Purwodadi.
\end{abstract}

Keywords: tobacco, nicotine, isolation, ethanol

\section{INTRODUCTION}

Tobacco is a strategic national economic commodity in Indonesia. As raw material of cigarettes, tobacco gives high income for Indonesia. Tobacco industry provides jobs for around 6,4 million people consists of 2,3 million tobacco farmers, 1,9 million clove farmers, 164.000 cigarette factory workers, 1,15 million retailers, and 900.000 other workers in finance, printing, and transportation sector [1]. The Indonesian kretek cigarette export market is currently affected. Many countries have signed the Framework Convention on Tobacco Control (FCTC) under the auspices of the World Health Organization (WHO). This condition will have a serious impact on livelihoods of millions of tobacco farmers around the world. Another impact of the FCTC is that tobacco farmers lose their livelihoods where this foreign decision will threaten the sources of income of 3.5 million tobacco farmers and clove farmers in Indonesia [2], [3].

Exploration of the potential of tobacco as a raw material of a hygienic product is one alternative solution for the sustainability of tobacco cultivation while increasing the empowerment of tobacco farmers. Nicotine is an alkaloid found predominantly in tobacco leaves [4]. Various solvent extraction can be used to isolate nicotine in tobacco leaves. Nicotine is widely used in fine chemical, pharmaceutical and agriculture industries, and in the tobacco industry itself as an essential cigarette additive [5]. One potential for tobacco is the conversion of nicotine from tobacco leaves into nicotinic acid or niacin.
Niacin a compound of Vitamin B3 which is widely used as medicine, vitamins, and cosmetics. This compound has a pyridine group and a carboxylate group as a side group so that the synthesis of nicotinic acid from nicotine from tobacco leaves can be done.

This study aims to isolate nicotine from tobacco leaves and find out the tobacco with the highest nicotine content. The design of this study is experimental laboratory. The tobacco leaves was taken from some regions in Indonesia namely Jember, Temanggung, Jogjakarta, Kediri, Lombok, Deli Serdang, Probolinggo, Blitar, and Purwodadi. Ethanol $96 \%$ was used to isolate the nicotine. The extraction process and the quantitatives analysis was carried out in Puslitbang Biomedis dan Teknologi Dasar Kesehatan. Quantitative analysis of nicotine compounds was performed using Gas Chromatography Mass Spectroscopy (GCMS).

\section{METHOD}

\section{Tobacco Leaves Samples:}

The tobacco leaves was taken from some regions in Indonesia namely Jember, Temanggung, Jogjakarta, Kediri, Lombok, Deli Serdang, Probolinggo, Blitar, and Purwodadi.

\section{Standards and Reagents:}

Nicotinine standard were acquired from Sigma Aldrich, ethanol pa. $96 \%$. 


\section{Extraction Method:}

The dried tobacco leaves are mashed using a fitzmill to powder. A total of $50 \mathrm{~g}$ of tobacco leaf powder was extracted with $500 \mathrm{ml}$ of $96 \%$ ethanol. Samples were allowed to stand for 24 hours. The extract was filtered and the filtrate was evaporated with a rotary evaporator until thick. The thick extract was dried on water bath until the extract weight remains constant [6].

\section{Standard Preparation:}

A 5000 ppm stock standard solution of nicotine was prepared in ethanol $96 \%$. Standard solutions of different concentrations (100 ppm, $200 \mathrm{ppm}, 400 \mathrm{ppm}, 600 \mathrm{ppm}$, $800 \mathrm{ppm}$, and $1000 \mathrm{ppm}$ ) of nicotine were prepared by serial dilution with distilled water for the construction of calibration curve.

\section{Sample Preparation:}

Each tobacco extract $(50 \mathrm{mg})$ was weighed. Five mililiters of ethanol $96 \%$ was added into the bottle filled with the tobacco extract and placed in sonicator for 15 minutes. The mixture was transferred into $25 \mathrm{ml}$ volumetric flask and the ethanol $96 \%$ was added. Each sample filtered through a $0.45 \mu \mathrm{l}$ PTFE filter prior to GCMS analysis.

\section{Chromatographic Conditions:}

GC-MS analyses were performed on Agilent 6890 GC coupled with Agilent 5975B inert XL mass spectrometer detector. The column was fused-silica capillary, DB-5 MS Column (30 m x 0,25 mm I.D. $\times 10,1 \mu \mathrm{m}$ film thickness). GC-MS analyses were performed with mass spectrometer detector. Helium was used as carrier gas at a constant flow $1,5 \mathrm{ml} \mathrm{min}-1$. One micro liter injection volume using splitless mode was programmed from 70 to $230^{\circ} \mathrm{C}(1 \mathrm{~min}$ hold $)$ at rate of $25^{\circ} \mathrm{C}$ min-1. Post run was set at $310^{\circ} \mathrm{C}$ for $6 \mathrm{~min}$. Total run time was $6.9 \mathrm{~min}$. The interface temperature was set at $280^{\circ} \mathrm{C}$. Selection ion monitoring (SIM) mode was used in analysis. Operation of the MSD was in the electron impact (EI) mode at 70 $\mathrm{eV}, 230^{\circ} \mathrm{C}$. The major ions peaks using the scan mode (50-180 a.m.u) were $\mathrm{m} / \mathrm{z} 84$ and 162 for nicotine with quantitation ions were $\mathrm{m} / \mathrm{z} 84$. A $100 \mathrm{~ms}$ dwell time was used for all ions [7].

\section{RESULTS AND DISCUSSION}

Figure 1 shows the result of GCMS chromatogram for nicotine of tobacco extract that obtained from the ethanolic extraction. Mass spectroscopy was applied as detector in gas chromatography equipment. The sample was compared to nicotine standard as the control. There was one peak (the highest peak) in the sample chromatogram that was detected in the same retention time as the nicotine peak in the control. It was indicated that the nicotine compound was detected qualitatively in that peak appeared in 5 minute of retention time as well as the peak of nicotine standard. It was also confirmed by the library tools in the GCMS equipment.

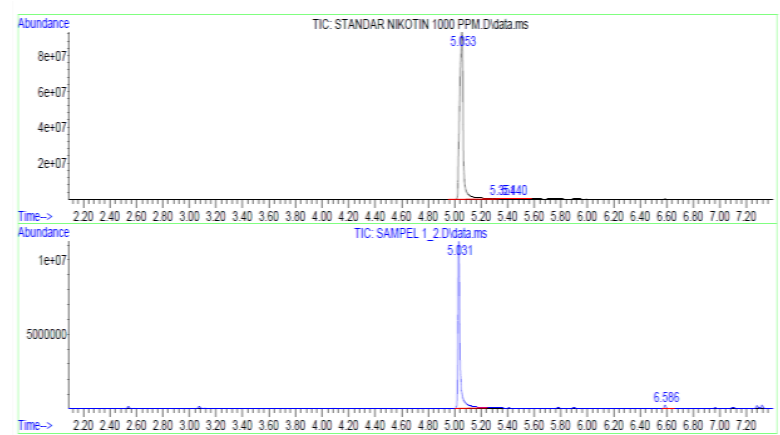

Figure 1. Gas chromatography mass spectroscopy (GCMS) chromatogram of the nicotine standard and nicotine tobacco leaf sample

Nicotine is the major alkaloid found in tobacco. It is confirmed by the chromatogram of the sample shown in Figure 1. The peak of nicotine was the highest peak compared to other peak in chromatogram, the spectrum of the nicotine standard and samples were shown in Figure 2 and Figure 3. Both standard and sample had similar fragments of nicotine.

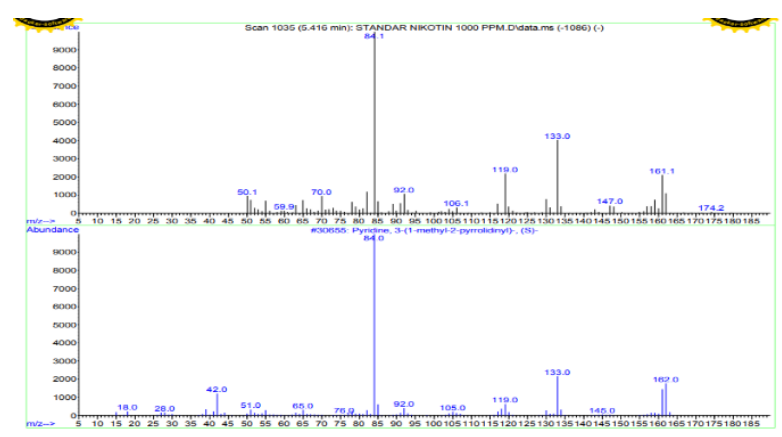

Figure 2. Mass spectrum of nicotine standard compared to nicotine spectrum in library tools

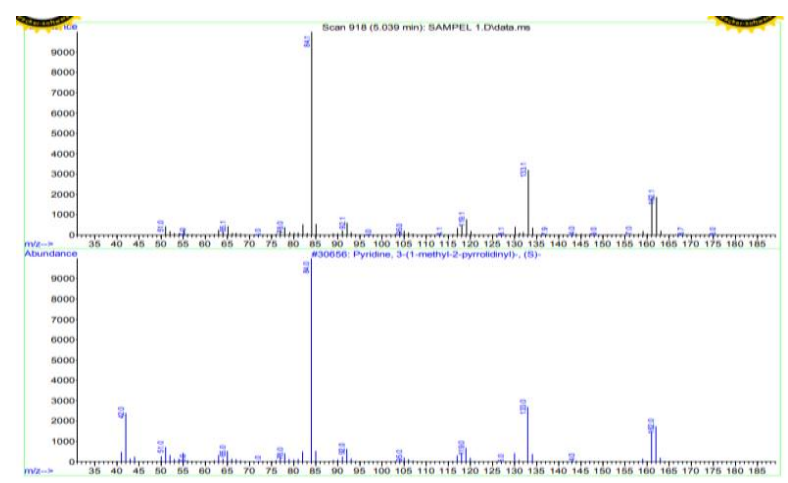

Figure 3. Mass spectrum of nicotine in samples compared to nicotine spectrum in library tools

The peak found in chromatograms was analyzed to determine nicotine yield in tobacco extract. The calculated results was shown in Table 1 . 


\section{ACKNOWLEDGMENT} tobacco leaf samples

\begin{tabular}{|c|c|c|c|}
\hline Tobacco leave & $\begin{array}{c}\text { Yield of } \\
\text { tobacco } \\
\text { extract } \\
(\%)\end{array}$ & $\begin{array}{c}\text { Nicotine } \\
\text { in extract } \\
(\%)\end{array}$ & $\begin{array}{c}\text { Nicotine } \\
\text { in } \\
\text { simplisia } \\
(\%)\end{array}$ \\
\hline Purwodadi & 8.19 & 0.63 & 2.53 \\
\hline $\begin{array}{c}\text { Lombok } \\
\text { (Kasturi) }\end{array}$ & 10.06 & 1.14 & 2.28 \\
\hline $\begin{array}{c}\text { Kediri } \\
\text { (Virginia) }\end{array}$ & 7.36 & 0.78 & 1.56 \\
\hline $\begin{array}{c}\text { Temanggung } \\
\text { Purbolinggo } \\
\text { (Paiton) }\end{array}$ & 5.40 & 0.56 & 1.12 \\
\hline Jogjakarta & 9.97 & 0.26 & 0.52 \\
\hline Deli (quality 1) & 5.40 & 0.11 & 0.43 \\
\hline Deli (quality 2) & 3.69 & 0.09 & 0.19 \\
\hline $\begin{array}{c}\text { Jember } \\
\text { (Samporis) }\end{array}$ & 0.78 & 0.04 & 0.08 \\
\hline Blitar & 9.76 & NA & NA \\
\hline
\end{tabular}

The result showed the nicotine content of tobacco cultivated in some regions in Indonesia was varied. The highest content of nicotine found in tobacco sample from Purwodadi. It was reported in other publication that nicotine content in Temanggung tobacco was $4-8 \%{ }^{8}$ Different result shown in this study, nicotine content in Temanggung tobacco was only $1.12 \%$. The yield of nicotine obtained in this study was very low. The isolation method of nicotine must be developed to obtain high nicotine yield.

\section{CONCLUSION}

The nicotine contained in tobacco leaves has been isolated by the ethanol solvent. The highest nicotine content was in tobacco leaf sample from Purwodadi. Further study needed to find the more efficient isolation process to increase the yield of nicotine and purification process must be performed to get high purity of nicotine isolate that can be used as raw material for hygienic products.
This project was supported by the DIPA fund of Puslitbang Biomedis dan Teknologi Dasar Kesehatan, Ministry of Health, Republic of Indonesia.

\section{REFERENCES}

[1] Rachmat M, Nuryanti S. Dinamika agribisnis tembakau dunia dan implikasinya bagi Indonesia. InForum Penelitian Agro Ekonomi. 2016;27(2):73-91.

[2] Shibuya K, Ciecierski C, Guindon E, Bettcher DW, Evans DB, Murray CJ. WHO Framework Convention on Tobacco Control: development of an evidence based global public health treaty. BMJ: British Medical Journal. 2003;327(7407):154.

[3] World Health Organization. WHO framework convention on tobacco control. Geneva, 2003.

[4] Fathi RM, Fauzantoro A, Rahman SF, and Gozan M. Column chromatography isolation of nicotine from tobacco leaf extract (Nicotiana tabaccum L.). AIP Conference Proceedings 1933, 030011 (2018); doi: $10.1063 / 1.5023958$

[5] Hu RS, Wang J, Li H, Ni H, Chen YF, Zhang YW, et.al. Simultaneous extraction of nicotine and solanesol from waste tobacco materials by the column chromatographic extraction method and their separation and purification.Separation and Purification Technology. 2015;146:1-7.

[6] Sholehah DN. Uji Aktifitas Anti Rayap Tembakau Dan Salak Madura. Agrovigor. 2011;4(1):38-41.

[7] Dural E, Kaya IB, Boran E, and Soylemezoglu T. Validation of GC-MS Method for Determination of Nicotine and Cotinine in Plasma and Urine. International Journal for Research in Applied Science \& Engineering Technology (IJRASET). 2017;5(IX):1748-52.

[8] Nurnasari E, Subiyakto. Komposisi kimia minyak atsiri pada beberapa tipe daun tembakau (Nicotiana tabacum L.). Berita Biologi. 2011;10(5):571-80. 